\title{
Dependence of the Yield of Chemical Coking Products from Coal Concentrates on Their Nature
}

\author{
Vasileva Elena V., , Cherkasova Tatyana G. ${ }^{\text {b }}$, Subbotin \\ Sergey P. ${ }^{\mathrm{c}}$, \\ Nevedrov Aleksandr V. ${ }^{\mathrm{d}}$, Papin Andrey V. ${ }^{\mathrm{e}}$ \\ T. F. Gorbachev Kuzbass State Technical University \\ Kemerovo, Russian Federation \\ akleossa@yandex.ru, ${ }_{2}{ }^{\text {ctg.htnv } @ \text { kuzstu.ru, }}$ \\ sybbotin@mail.ru, \\ dnevedrov1978@ rambler.ru. ${ }_{2}$ papinandrey@ rambler.ru
}

\author{
Kolmakov Nikolay G. \\ OAO"Koks" \\ Kemerovo, Russian Federation
}

\begin{abstract}
The relevance of the work is justified by the need for a comprehensive assessment of the quality of coal concentrate used to produce coal blends in the coking process, and resources of coking chemical products derived from them. This information is necessary for making optimal coal blends for coking and for planning of coking plants operation. The purpose of work is to study the impact of the qualitative characteristics of the Kuznetsk Basin coal concentrates on the yield and composition of coking chemical products for the purpose of making coal blends for coking on their basis. In the course of studies, the following indicators have been identified: the technical analysis, caking, petrographic analysis, the yield of chemical coking products from coal concentrates and strength of the resulting coke residue. The main results of the study are the data on the main indicators of the quality of the investigated coals of the Kuznetsk basin and the coking yield as well as the relationships between these parameters. The results will later be used in the preparation of optimal coal blends for coking in the real production conditions of OAO "Koks".
\end{abstract}

Keywords - coal, coal blend, coking, coke, coking chemical products.

\section{INTRODUCTION}

In the context of a deteriorating resource base of coking and scarcity and high cost of coking coal [1] [2] [3], the role of forecasting as a form of research in the modern coking industry [4] increases. The instability and heterogeneity of the raw materials for coking by technological properties, uneven supply of coal affect both the quality of the coke, and the yield of chemical products of coking. Under these conditions the value of estimation of chemical products resource in coking coals and coal blends increases as well as the quality of the products[5] [6].

The coke produced in the recent years (the average across Russia) belongs to the average quality category by strength. Therefore, the development of Russian coke plants, industry institutes, as well as foreign companies perform studies trying to improve the quality of coke strength. As a result, there is a transition in the main study to determine the reactivity of coke (CRI) and a post-durability (CSR), and the value of other parameters of strength and abrasion is underestimated which is unacceptable [7] [8]. The situation is deteriorated by the fact that the decision of problems of a substantial improvement of coke quality is possible mainly by attracting deficit coal grades. The use of such high-value coal improves coke quality with its inevitable rise in prices. At the same time, during periods when the coke quality, especially by abrasion $\left(\mathrm{M}_{10}\right)$, is deteriorating due to various reasons of coal raw nature, the coke worsens the indicators of blast furnace performance, becoming the dominant negative factor [9].

Currently, a significant portion of coal blend components is presented concentrates from coal preparation plants (CPP). The concentrates are usually a mixture of several grades of coals and cannot be attributed to a specific mine group under the standard GOST 25543-2013 [10]. Also in connection with the situation in the coal market it is often not possible to ensure supplies of the requested coal grades to the coke enterprises. Therefore, it is required to select the optimum ratio of coal concentrates to get the highest possible quality of coke for blast furnaces. In making coal blends it is necessary to make full use of caking, coking and inert potentials of the available components. This is easily done when the components are uniform in grade composition. In practice, we have to work with different brands and types of coal, which number in the mixtures reaches nine to fifteen, that is why the problem of assessing the complicated grade composition and types of coal concentrates at CPPs deserves special attention [11]. Under these conditions, in addition to the classical methods of analysis of coal quality on the basic parameters of technical analysis, caking and petrographic analysis, it is also required to assess the structure and yield of chemical products of coking, since they are a source of valuable chemicals.

In the process of coking, in addition to the basic product (coke) the following volatile products are produced: coke oven gas, pyrogenic water, naphthalene, ammonia, hydrogen sulphide (and other sulfur compounds.), Cyanides, benzene hydrocarbons, coal tar, and others [12]. The yield of these products significantly affects the economics of production, for example, of benzene, hydrocarbons and coal tar which are valuable products of coke production, which can easily find the consumer, while others are unwanted, which implies their disposal costs.

The study of the regularities in the yield of chemical products in coking of various coals and coal blendcharge to 
predict the output of chemical products in the coking process is a very important practical problem, as the chemical nature of the coal and the conditions of occurrence of coking process are the main factors affecting the yield and quality of these products [13].

Composition and yield of chemical products in coking largely depend on the mode of coking oven performance and, in particular, on the temperature of the coking process, the pressure in the coke oven chamber, and the size of subroof space and single charge of the blend.

The nature of coals has a major impact on the structure and yield of chemical products of coking. With an increase in the yield of volatiles substances the yield of coke oven gas increases, and significantly increases its calorific value, due to a high content of methane and heavy hydrocarbons, but the coke yield is lowered. Increasing the proportion of the gas in the current charge of coal leads to an increase in yield of coke and gas contained carbon oxides $(\mathrm{CO}, \mathrm{CO} 2)$, and an increase in the yield of resin and crude benzol. The change in the yield of tar and benzene hydrocarbons also depends on the release of volatile substances and grades of coals. With an increasing yield of volatile substances, the yield of tar and benzene hydrocarbons increases, but with significant variations for the same brand of coal. The release of pyrogenetic moisture depends on the oxygen content in the coals, which decreases with increasing degree of metamorphism. The ammonia output doesn't depend on the yield of coal volatiles, and is directly linked to nitrogen transformations as a result of coal thermal degradation. Yield of sulfur compounds also depends on the content and type of sulfur in the coal. The primary coke sulfur compound is hydrogen sulfide gas, in smaller quantities it also contains mercaptans, carbon disulfide, thiophenes, and so on.

This direct relationship between the nature of coal, characterized by a content of volatile substances, the degree of metamorphism and other characteristics of the coals, and the output of chemical products of coking are not observed. Identified patterns are due to the fact that in addition to the coal grade, its origin and formation conditions impact the yield of coking products [14]. Therefore, the research of the yield of chemical products of coking from the coals of the Kuznetsk Basin is very important for optimal preparation of coal blends for coking production.

\section{MATERIALS AND METHODS}

In order to solve the problem of obtaining good quality coke, the study was made of the quality of coals of the Kuznetsk basin used as the raw material base for OAO "Koks" (Kemerovo), since due to its geographical location, the company' resource base is focused mainly on the coals of the Kuznetsk Basin. In the course of research, the technical analysis of used coal concentrates was made. The indicators of the technical analysis of samples of coal were determined as follows: ash content of coals and mixtures thereof - according to GOST R 55661-2013 "Solid mineral fuel. Methods for determination of ash content"[15], volatile substances according to GOST 6382-2001"Solid mineral fuel. Methods for determining the release of volatile substances"[16], GOST 11014-2001"Coal and peat, anthracite and combustible shales. Accelerated methods for determining the moisture"[17] was used to determine the moisture applied analytical.

Swelling index SI in the crucible was determined by the method specified in GOST 20330-91 "Coal. determining the swelling index in the crucible" [18]. For these coals, the analysis of chemical products output of coking was also conducted following the procedure provided in the GOST 18635-73 "Coal.Method for determining the output of coking chemical products"[19]. This method is accurate, reproducible and correlates well with indicators of technological output of coking chemical products [20].

\section{RESULTS}

The results of the technical analysis of studied coal concentrates are presented in Table1.

The results of determination of the yield of chemical products of coking coal concentrates study are presented in table2.

TABLE I. Technical Analysis Of Coal Concentrates

\begin{tabular}{|c|c|c|c|c|c|c|c|c|}
\hline Name of sample & Grade & $\mathbf{A}^{\mathrm{d}}, \%$ & $\begin{array}{c}\mathbf{V}^{\text {daf }} \\
\text {, }\end{array}$ & $\mathbf{R}_{\mathbf{0}}, \%$ & $\begin{array}{l}\text { Vt, } \\
\%\end{array}$ & $\mathbf{S}_{\mathrm{t}}^{\mathrm{d}}, \boldsymbol{\%}$ & $\begin{array}{c}\mathbf{y}, \\
\mathbf{m m}\end{array}$ & SI \\
\hline Concentrating plant"Berezovskaya" ("Site"Coke"”) & K & 7.2 & 21.0 & 1.267 & 54 & 0,34 & 13 & 5 \\
\hline Concentrating plant"Berezovskaya"(Mine "Sergeyevsky") & $\mathrm{K}$ & 6.2 & 24.0 & 1.044 & 71 & 0.44 & 16 & $51 / 2$ \\
\hline Concentrating plant"Berezovskaya" & $\mathrm{KO}+\mathrm{KC}$ & 6.8 & 21.8 & 1.046 & 41 & 0.36 & 10 & 2 \\
\hline Concentrating plant"Berezovskaya" & $\Gamma Ж+\mathrm{KO}$ & 6.7 & 30.0 & 0.803 & 72 & 0.49 & 16 & 7 \\
\hline Concentrating plant"Berezovskaya" & ГЖ+КО+КС & 7.6 & 29.5 & 0.807 & 75 & 0.44 & 15 & 4 \\
\hline Concentrating plant "Mezhdurechenskaya" & $\mathrm{OC}$ & 11.6 & 19.8 & 1.335 & 51 & 0.17 & 12 & 3 \\
\hline Concentrating plant"Antonovskaya" & ГЖ & 8.9 & 33.8 & 0.758 & 86 & 0.41 & 19 & $71 / 2$ \\
\hline Concentrating plant "Antonovskaya" & ГЖ+Ж & 10.9 & 34.0 & 0.790 & 89 & 0.50 & 24 & 8 \\
\hline Concentrating plant"Taybinskaya" & $\mathrm{K}$ & 9.1 & 19.0 & 1.155 & 62 & 0.31 & 13 & $3 \frac{1}{2}$ \\
\hline Concentrating plant"Taybinskaya" & $\mathrm{OC}$ & 8.4 & 18.8 & 1.274 & 50 & - & 12 & 3 \\
\hline Concentrating plant"Prokopevskaya" & K & 7.3 & 24.7 & 1.174 & 41 & 0.33 & 13 & $1 / 2$ \\
\hline Concentrating plant"Northern" & $\mathrm{K}$ & 8.5 & 24.2 & 1.064 & 58 & 0.32 & 13 & 3 \\
\hline Mine“Apsatskiy” & $\mathrm{K}$ & 9.9 & 26.1 & 1.178 & 75 & 0.37 & 17 & $61 / 2$ \\
\hline Mine "Butovskaya" & KO & 10.2 & 20.6 & 1.269 & 50 & 0.42 & 12 & 1 \\
\hline Mine "Site"Coke""” & KC & 6.3 & 18.9 & 1.351 & 40 & 0.34 & 11 & 1 \\
\hline Concentrating plant "Coke" & K & 9.5 & 18.0 & 1.434 & 58 & 0.38 & 14 & 4 \\
\hline
\end{tabular}


TABLE II. Yield Ofchemical Products Of Coking On The Dry Weight

\begin{tabular}{|c|c|c|c|c|c|c|c|c|c|}
\hline \multirow[b]{2}{*}{ Namesample } & \multirow[b]{2}{*}{$\stackrel{y}{\vdots}$} & \multicolumn{8}{|c|}{ Chemical products ofthe coking, \% } \\
\hline & & ن & 䍖 & $\mathbf{Z}$ & 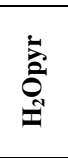 & $\stackrel{M}{ت}$ & ¿ & 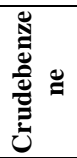 & $\begin{array}{l}+\mathscr{U} \\
\tilde{E} \\
\tilde{\Xi} 气\end{array}$ \\
\hline $\begin{array}{c}\text { Concentrating plant } \\
\text { "Berezovskaya" ("Site“Coke"”) }\end{array}$ & K & 83.90 & 3.13 & 0.61 & 0.97 & 0.21 & 0.40 & 0.62 & 10.16 \\
\hline $\begin{array}{c}\text { Concentrating plant "Berezovskaya" } \\
\text { (Mine "Sergeyevsky") }\end{array}$ & K & 79.56 & 1.95 & 0.73 & 3.08 & 0.29 & 0.62 & 0.64 & 13.13 \\
\hline $\begin{array}{l}\text { Concentratingplant } \\
\text { "Mezhdurechenskaya" }\end{array}$ & $\mathrm{OC}$ & 82.05 & 2.05 & 0.73 & 2.03 & 0.27 & 0.81 & 0.47 & 11.59 \\
\hline Concentrating plant"Taybinskaya" & K & 83.43 & 2.62 & 0.67 & 2.71 & 0.18 & 0.75 & 0.60 & 9.04 \\
\hline Concentrating plant"Taybinskaya" & $\mathrm{OC}$ & 81.40 & 1.59 & 0.74 & 2.55 & 0.23 & 0.46 & 0.54 & 12.49 \\
\hline Concentrating plant"Antonovskaya" & ГЖ & 70.67 & 5.50 & 0.69 & 4.31 & 0.45 & 1.39 & 1.29 & 15.70 \\
\hline Concentrating plant"Antonovskaya" & ГЖ+Ж & 72.11 & 5.26 & 0.81 & 3.55 & 0.49 & 0.68 & 1.67 & 15.43 \\
\hline Concentrating plant "Berezovskaya" & $\mathrm{KO}+\mathrm{KC}$ & 78.26 & 3.85 & 0.71 & 2.22 & 0.30 & 0.58 & 0.79 & 13.29 \\
\hline Concentrating plant "Berezovskaya" & ГЖ+КО & 73.31 & 5.68 & 0.76 & 2.82 & 0.45 & 0.71 & 1.21 & 15.06 \\
\hline $\begin{array}{l}\text { Concentrating plant } \\
\text { "Berezovskaya" }\end{array}$ & ГЖ+КО+КС & 73.67 & 4.17 & 0.77 & 3.42 & 0.26 & 1.18 & 1.53 & 15.00 \\
\hline Concentrating plant "Prokopevskaya" & $\mathrm{K}$ & 76.42 & 3.17 & 0.67 & 3.95 & 0.28 & 1.00 & 0.86 & 13.65 \\
\hline Concentrating plant"Northern" & $\mathrm{K}$ & 78.44 & 2.97 & 0.66 & 2.79 & 0.30 & 0.77 & 0.94 & 13.13 \\
\hline Mine"Apsatskiy" & $\mathrm{K}$ & 77.32 & 3.27 & 0.40 & 3.58 & 0.30 & 0.76 & 0.74 & 13.63 \\
\hline Mine "Butovskaya" & KO & 79.90 & 2.93 & 0.56 & 2.83 & 0.33 & 0.40 & 0.59 & 12.46 \\
\hline Mine "Site"Cok"" & KC & 81.51 & 2.26 & 0.61 & 1.39 & 0.19 & 0.84 & 0.42 & 12.78 \\
\hline Concentrating plant"Coke" & K & 83.25 & 1.97 & 0.53 & 2.01 & 0.24 & 0.62 & 0.50 & 10.88 \\
\hline
\end{tabular}

The resulting output of chemicals determining coking coke strength was tested at the lower output classes of small $(<1 \mathrm{~mm})$.The method consists in determining the coke test chemicals exit coking drum horn and plating the resulting producton a sieve having meshes of $1 \mathrm{~mm}$.

The results of the study of small class output from coke yield determination chemical coking products are shown in Table. 3.

TABLE III. Yield Of Small Classes Of Coke Determine The Yield Of Coking Chemical Products

\begin{tabular}{|c|c|c|c|}
\hline \multirow[t]{2}{*}{ Namesample } & \multirow[t]{2}{*}{ Mark } & \multicolumn{2}{|c|}{$\begin{array}{c}\text { Out of } \\
\text { small } \\
\text { classes } \\
\text { after the } \\
\text { test }(<1 \\
\text { mm),\% }\end{array}$} \\
\hline & & $\begin{array}{c}15 \\
\min \end{array}$ & $\begin{array}{c}30 \\
\min \end{array}$ \\
\hline $\begin{array}{c}\text { Concentrating plant "Berezovskaya" } \\
\text { ("Site"Coke") }\end{array}$ & K & 3.3 & 5.8 \\
\hline $\begin{array}{c}\text { Concentrating plant "Berezovskaya" } \\
\text { (Mine "Sergeyevsky") }\end{array}$ & K & 2.0 & 3.6 \\
\hline Concentrating plant "Berezovskaya" & $\mathrm{KO}+\mathrm{KC}$ & 6.3 & 10.3 \\
\hline Concentrating plant "Berezovskaya" & ГЖ+КО & 7.3 & 12.0 \\
\hline Concentrating plant "Berezovskaya" & ГЖ+КО+КС & 4.0 & 6.2 \\
\hline $\begin{array}{l}\text { Concentratingplant } \\
\text { "Mezhdurechenskaya" }\end{array}$ & $\mathrm{OC}$ & 35.5 & 47.2 \\
\hline Concentratingplant“Antonovskaya” & ГЖ & 11.1 & 18.6 \\
\hline Concentratingplant"Antonovskaya” & ГЖ+Ж & 19.0 & 25.8 \\
\hline Concentratingplant"Taybinskaya" & $\mathrm{K}$ & 5.1 & 11.2 \\
\hline Concentratingplant"Taybinskaya" & $\mathrm{OC}$ & 37.8 & 49.1 \\
\hline Concentratingplant"Prokopevskaya" & K & 74 & 91.5 \\
\hline Concentratingplant"Northern" & $\mathrm{K}$ & 3.1 & 5.5 \\
\hline Mine“Apsatskiy" & $\mathrm{K}$ & 7.5 & 13.9 \\
\hline Mine "Butovskaya" & КО & 17.2 & 27.6 \\
\hline Mine "Site"Coke"" & KC & 20.0 & 32.6 \\
\hline Concentratingplant"Coke" & $\mathrm{K}$ & 5.8 & 9.2 \\
\hline Coke factory & - & 3.5 & 6.9 \\
\hline
\end{tabular}

\section{DISCUSSIONS}

Based on experimental data, we can conclude that the non-volatile coke residue obtained by determining the output of chemical products of coking coal concentrate by concentrating plant "Berezovskaya" (mine "Site"Coke"",mine "Sergeyevsky" (mark K), and the mixture mark $\Gamma Ж+K O+K C)$, concentrating plant «Northern» (mark K), has a strength comparable to the strength of the coke plant.

The formation of sintered non-volatile residue test result indicates the presence of not only the caking, but, as nonvolatile residue formation fact of sintering ability. The plastic layer is formed by heating coal in the temperature range $370-890{ }^{\circ} \mathrm{C}$ for coal gas-fat group and $430-890^{\circ} \mathrm{C}$ for a coke group, it is a complex heterogeneous system. This system consists of organic macromolecules passing into the liquid state, solid organic or inorganic inclusions in the liquid phase and the gases released during heating. The majority of coal transferred to the liquid state, the greater is the degree of wetting of the coal particles and the process of filling the space between them. With further increase in temperature increases the viscosity of the plastic mass occurs caking of solid coal particles, and then sintering the plastic mass, which leads to solidification (bead formation).

However, too much plastic mass does not improve the strength properties of the non-volatile residue, and degrades them. This is because that increases the distance between the solid coal particles that are sintered with a simultaneous increase in gas evolution, which leads to reduced strength formed conglomerates.

Each coal concentrate has a certain caking ability, sintering and coking capacities. For non-volatile residue with high strength characteristics of the original sample 
should have the following parameters: $25 \leq \mathrm{V}^{\mathrm{daf}} \leq 33 \%$; in $\geq$ $16 \mathrm{~mm} ; 1.0 \leq \mathrm{R}_{\mathrm{o}} \leq 1.1$. These include scarce coking coals grade $\mathrm{K}$, but these requirements can meet and mix different brands [21]. This, in our opinion, can be attributed to the experimental data.

Based on the results of the technical analysis of the coals and the yield of coking chemical products the dependences were built of the yield of basic chemical coking products on the degree of coking coal metamorphism expressed by the yield of volatile substances and the vitrinite reflection index and on maseral composition expressed by the vitrinite content. Dependences of the yields of coke, tar and crude benzene on the yield of volatiles of coal concentrates are shown in Fig. 1.

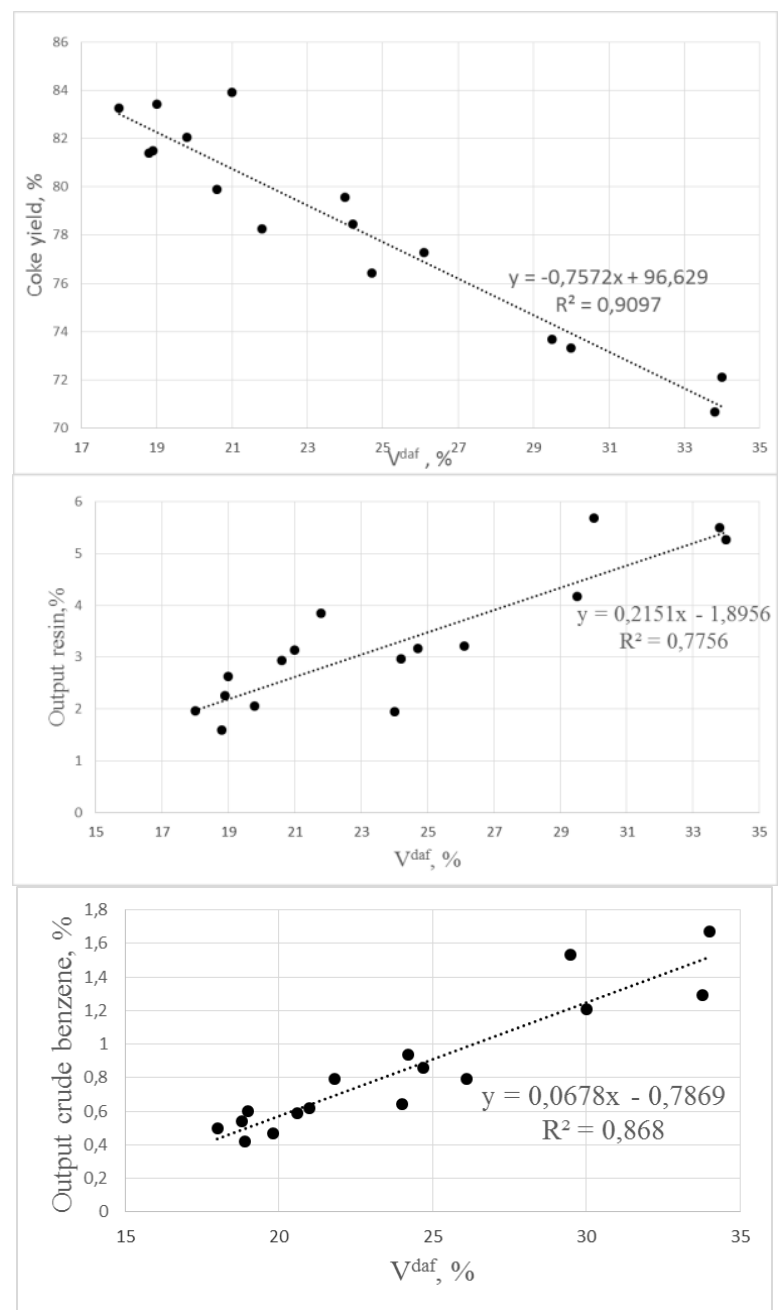

Fig. 1. Dependences of the yields of coke, resin and crude benzol on the yield of volatiles of coal concentrates

The analysis of the data shows that with an increase in the yield of volatiles the yield of tar and benzene hydrocarbons is increased, but with significant variations for the same grade of coal. The yield of coke, on the contrary, decreases. This is consistent with the data from Turik I.A., Kozina O.Ya., Gagarin S. G. [14][22][23].

Dependence of the coke yield, tar and crude benzene on the index of vitrinite reflectance of coal concentrates is shown in Fig. 2.

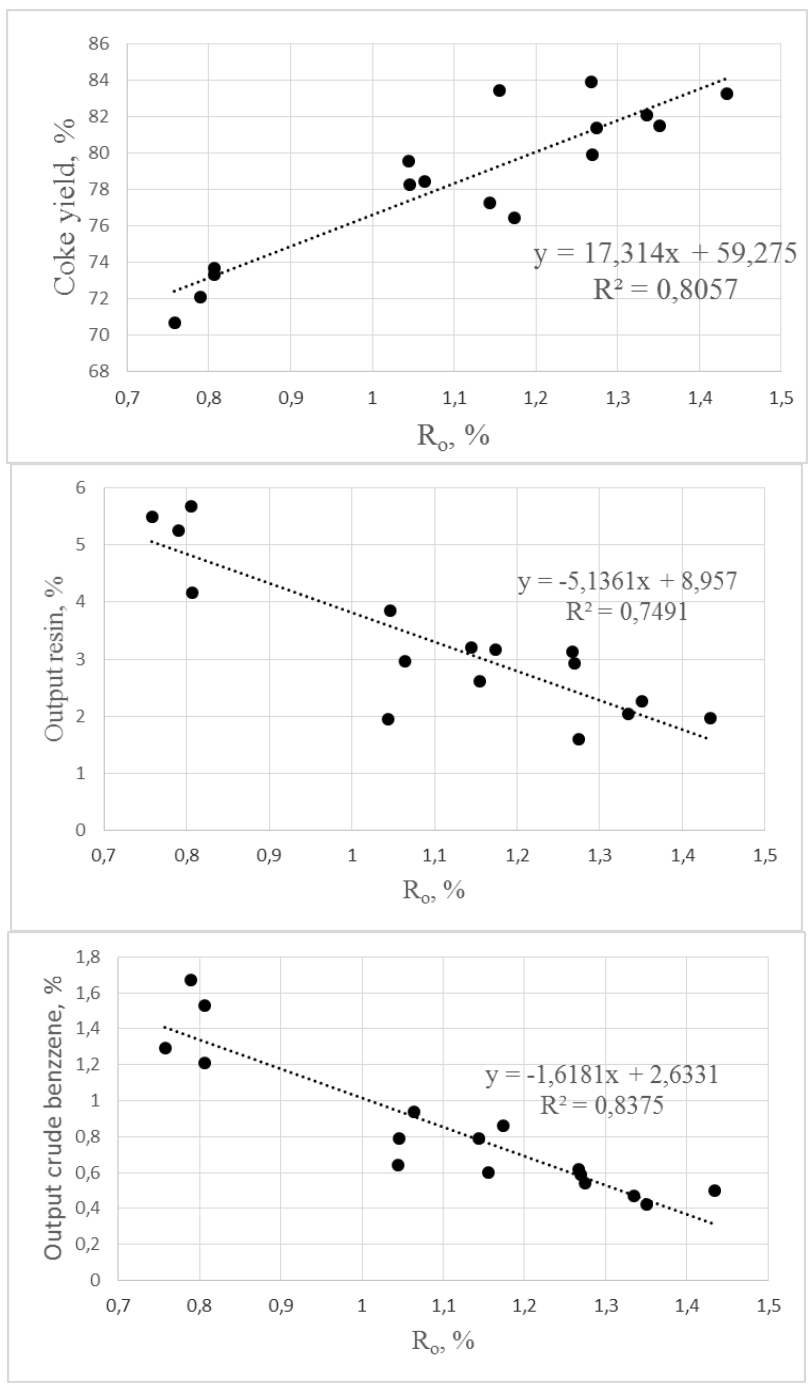

Fig. 2. Dependence of the yield of coke, resin and crude benzene on vitrinite reflectance index of coal concentrates

Thus, on the basis of the data obtained we can conclude that with the increase in vitrinite reflectance index values characterizing the increase in the degree of metamorphism, the yield of tar and benzene hydrocarbons decreases, but also with considerable fluctuations for the same grade of coal. The yield of coke, on the contrary, increases. Fluctuations of indicators in this case can be explained by differences in the degree of reduction of the investigated coals. This is consistent with the data from S. G. Gagarin, V.S. Zhdanov [24][25]. 
The results of the study of the yield of coke, resins, benzene and the vitrinite content in coal concentrates are shown in Table 1 and Table 2.

Analysis of the data shows that the yield of benzene and tar from coal and their mixtures increases with increasing of their vitrinite content. The yield of coke, on the contrary, decreases. This is consistent with data from S. G. Gagarin, M. B. Golovko, A. B. Danilov[26]. Fluctuations of indicators in this case can be explained by differences in the elemental composition of the investigated coal [27].

\section{CONCLUSION}

The methodology applied in the course of the research for determination of the yield of coking chemical products is characterized by a high degree of convergence of the data with those obtained in industrial conditions of OAO "Koks" in Kemerovo.

The obtained results of the research will improve the effectiveness of the use of coal grades in order to form the optimal composition of the coal blend for coking in order to improve the yield of coke and its quality.

\section{ACKNOWLEDGEMENTS}

The authors express their gratitude to the staff of OAO "Koks" (Kemerovo) for assistance and cooperation in scientific research.

The work was performed under of the project of the public order №10.782.2014K of the Ministry of Education and Science of the Russian Federation.

\section{REFERENCES}

[1] Vasil'eva E.V., Cherkasova T.G. "Investigation of the influence of qualitative characteristics of the Kuznetsk Basin coal concentrate output of chemical products of coking".Vestnik of Kuz.state tech. univ.,2015, \#4. - P. 105-111.

[2] Fedorova N.I., Zaostrovskij A.N., Zubakina V.A. "Chemical and technological properties of coking coal in Kuzbass". Vestnik of Kuz.state tech. univ.,2015, \# 5. - P. 121-125.

[3] Fedorova N.I., Trjasunov B.G. "Quality assessment weakly caking coal Kuzbass". Vestnik of Kuz.state tech. univ., 2014,\# 4. - P. 93-96.

[4]Golovko M.B., Miroshnichenko D.V., Kaftan Yu.S."Predicting the Coke Yield and Basic Coking Byproducts: An Analytic Review". CokeandChemistry, 2011,vol. 54, \# 9. - P. 331-338.

[5] Turik I.A., Alekseeva N.F., Babenko M.S."Output of chemical products of coking".Coke and Chemistry, 1988, \# 6. - P. 29-30.

[6]Gorelov P.N., Kotelenec M.S."Prediction of the main products of coking coal and mines for volatile substances and oxidation".Coke and Chemistry, 1987, \# 1. - P. 26-34.

[7] Lyalyuk V.P., Tarakanov A.K., Kassim D.A."Influence of the Reactivity of Coke on Blast-Furnace Performance".CokeandChemistry,2011,vol. 54, \# 2. - P. 47-52.

[8] Muchnik D.A., Babanin V.I., Zagainov V.S., Stakheev S.G."Processes for Boosting Coke Quality". Coke and Chemistry, 2011,vol. 54, \# 3. P. 94-98.

[9] Lakhtin S.N., Shashkov O.A., Mel'nikov I.I., ZolotukhinYu.A."Coke Quality at OAO MMK with Deterioration in Available Coal Resources". Coke and Chemistry, 2011,vol. 54, \# 12. - P. 433-441.

[10] GOST 25543-2013. Coal and peat and anthracite. Classification of genetic and technological parameters. - Moscow: FGUP "Standartinform", 2014. - 17 p.

[11] ZolotuhinJu.A., Stukov M.I., Kraskovskaja T.F. "Evaluation of technological properties of the complex on the grade composition and type of coal for coking".Coke and Chemistry, 1996, \# 1. - P. 2-6.
[12] KoljandrL.Ja. "Collection and processing of chemical products of coking". - .Harkov: Metallurgizdat, 1962. - 468 p.

[13] Kaufman A.A., Harlampovich G.D."The technology of coke production". -Ekaterinburg: VUHIN-NKA, 2005. - 288 p.

[14] Kozina O.Ya., Nekrasova T.P."Influence of the Rank Composition of Coal Batch and the Coking Temperature on the Yield and Quality of Chemical Products".Coke and Chemistry,2008,vol. 51, \# 2. - P. 68-69.

[15] GOST 11022-95. Solid mineral fuel.Methods for determination of ash. - Moscow: Izd-vostandartov, 2006. - 8 p.

[16] GOST 6382-2001. Solid mineral fuel.Methods for determining the release of volatile substances. - Moscow: Izd-vostandartov, 2000. - 16 p.

[17] GOST 11014-2001. Coal and peat, anthracite and combustible shales.Accelerated methods for determining moisture.-Moscow: Izdvostandartov, 2000. - $6 \mathrm{~s}$.

[18] GOST 20330-91. Coal.Method for determination of swelling index in the crucible. - Moscow: Izd-vostandartov, 1991. - 9 p.

[19] GOST 18635-73. Coals. Method for determining the output of coking chemical products. -Moscow: Izd-vostandartov, 2000. - $11 \mathrm{p}$

[20] Kotelec M.S.,Novikov V.N.,Gorelov P.N. "By standardizing laboratory method for determining the output of coking chemical products". Coke and Chemistry, 1977, \# 3. - P. 32-34.

[21] Stepanov E.N., Mezin D.A.,Chuikina O.V., Osipova I.V."Influence of Coking Conditions on the Carbon Content in Coke". Coke and Chemistry, 2011,vol. 54, \# 12. - P. 453-456.

[22] Turik I.A., Alekseeva N.F. "On the exit of coke gas from coal and batches". Coke and Chemistry, 1985, \# 12. - P. 18-20.

[23] Gagarin S.G. "The chemical potential of macerals and coal". Coke and Chemistry, 2000, \# 3. - P. 17-22.

[24] GagarinS.G. "Regression analysis of the structure and properties of macerals raznovosstanovlennyh coals of Kuzbass". Coke and Chemistry, 1998, \# 2. - P. 2-6.

[25] Golovko M.B., Drozdnik I.D., Miroshnichenko D.V., Kaftan Yu. S."Predicting the Yield of Coking Byproducts on the Basis of Elementary andPetrographic Analysis of the Coal Batch". Coke and Chemistry, 2012,vol. 55, \# 6. - P. 204-214.

[26] Danilov A.B., Verdibozhenko G.S., Drozdnik I.D., Miroshnichenko D.V., Kaftan Yu.S., Golovko M.B."Predicting the Yield of Coke-Plant Products on the Basis of Petrographic Analysis". Coke and Chemistry, 2012,vol. 55, \# 11. - P. 419-422.

[27] Ulanovskii M.L."Assessing the Utility of Coal's Elementary Composition in Predicting the Yield of Coking Products". Coke and Chemistry, 2012,vol. 55, \# 3. - P. 83-86. 